University of Nebraska - Lincoln

DigitalCommons@University of Nebraska - Lincoln

Spermatogenesis in the turkey (Meleagris gallopavo): Quantitative approach in immature and adult males subjected to various photoperiods

Jérôme Noirault

INRA

Jean-Pierre Brillard

I.N.R.A., brillard@tours.inra.fr

Follow this and additional works at: https://digitalcommons.unl.edu/usdaarsfacpub

Part of the Agricultural Science Commons

Noirault, Jérôme and Brillard, Jean-Pierre, "Spermatogenesis in the turkey (Meleagris gallopavo): Quantitative approach in immature and adult males subjected to various photoperiods" (2006).

Publications from USDA-ARS / UNL Faculty. 674.

https://digitalcommons.unl.edu/usdaarsfacpub/674

This Article is brought to you for free and open access by the U.S. Department of Agriculture: Agricultural Research Service, Lincoln, Nebraska at DigitalCommons@University of Nebraska - Lincoln. It has been accepted for inclusion in Publications from USDA-ARS / UNL Faculty by an authorized administrator of DigitalCommons@University of Nebraska - Lincoln. 


\title{
Spermatogenesis in the turkey (Meleagris gallopavo): Quantitative approach in immature and adult males subjected to various photoperiods
}

\author{
Jérôme Noirault ${ }^{\mathrm{a}}$, Jean-Pierre Brillard ${ }^{\mathrm{a}, *}$, \\ Murray R. Bakst ${ }^{\mathrm{b}}$ \\ a I.N.R.A., Station de Recherches Avicoles, Centre de Tours, 37380 Nouzilly, France \\ ${ }^{\mathrm{b}}$ Biotechnology and Germplasm Laboratory, ARS, USDA, Beltsville, MD 20705, USA
}

Received 24 May 2004; accepted 31 January 2005

\begin{abstract}
The objectives of this study were to identify and quantitate the germ cell populations of the testes in sexually mature male turkeys (Trial 1), determine the duration of meiosis based on BrdU labeling and stereological analyses (Trial 2), and examine the impact of various photoperiods on germinal and somatic cell populations in immature and adult males (Trial 3). In Trial 1, both testes within a male had similar stereological components $(P>0.05)$ for all parameters analyzed. In Trial 2 , the duration of Type-1 spermatocytes and round spermatids in turkeys lasted $4.5 \pm 0.5$ and $2.0 \pm 0.5$ days, respectively. In Trial 3, the short photoperiod (7L:17D) delayed testicular growth (in the stereological parameters analyzed). In contrast, the effect of a moderately short photoperiod (10.5L:13.5D) was comparable to the effect of a long (14L:10D) or increasing photoperiod (7L:17D to $14 \mathrm{~L}: 10 \mathrm{D})$ on the stereological parameters examined. With the exception of the short photoperiod, all other photoperiods used in this study induced comparable early testicular maturation, with maximum testis
\end{abstract}

Abbreviations: El, elongated spermatids; Fwt, testes fragment weight; MR, meiotic ratio; $\varnothing$, seminiferous tubule diameter; $\theta$, mean lifespan; nSert, Sertoli cell counts; nSpcI, primary spermatocyte counts; nSpdR, round spermatid counts; NSert, total number of Sertoli cells per testes; NSpcI, total number of Type-I spermatocytes per testes; NSpdR, total number of round spermatids per testes; Sert, Sertoli cells; SE, seminiferous epithelium; Spg, spermatogonia; Spc I, Type-I spermatocytes; SpcII, Type-II spermatocytes; SpdR, round spermatids; ST, seminiferous tubule; Tspz, testicular spermatozoa; TSP, testicular sperm production; $V_{\mathrm{r}}$, relative volume

* Corresponding author. Tel.: +3324742 7645; fax: +33247427778.

E-mail address: brillard@ tours.inra.fr (J.-P. Brillard). 
weight at 29-35 weeks of age. As the males got older, there was a progressive, linear decline in testis weight through 60 weeks, at which time there were no significant differences among photoperiods. In conclusion, the duration of meiosis in the turkey was similar to that observed in the fowl and guineafowl. The existence of a threshold of photosensitivity to gonad stimulation in male turkeys is suggested to be between 7.0 and $10.5 \mathrm{~h}$ of light.

(C) 2005 Elsevier Inc. All rights reserved.

Keywords: Photostimulation; Turkey; Poultry; Spermatogenesis; Semen production

\section{Introduction}

Quantitative studies on the impact of various photoperiods on the stereology and morphology of cells forming the seminiferous epithelium (SE) in domestic avian species are scarce; they are limited to works by Kumaran and Turner [1] and de Reviers [2] in fowl, Clulow and Jones [3] in Japanese quail, Marchand and Gomot [4] in ducks, and Brillard [5] in guinea-fowl. Cellular associations between specific stages of spermatogenesis have been described; they have facilitated quantitative studies of mammalian spermatogenesis [6,7]. In contrast, such associations in avian species, if they exist, have limited value to quantitate spermatogenesis, due to the existence of atypical stages [8-10]. The difficulty in describing such cellular associations in the avian SE is probably due to the relatively rapid transitions of certain germ cell categories [11]. Overall, the various stages of spermatogenesis in avian species appear to be of shorter duration than corresponding stages in mammals [12,13]. For example, while the time from the onset of meiosis to the end of spermiogenesis is about 26 days in the mouse [14], 29.5 days in the ram [15], 37 days in the bull [16], and 45.5 days in human [17], it is only 14 days in the fowl or drake [12,13], 11 days in the quail [18] and 14 days in guinea-fowl [19].

From a quantitative perspective, the efficiency of spermatogenesis is reflected in the number of spermatids derived from a single spermatocyte and on the ability of a given spermatid to transform into a functional spermatozoa. This efficiency is a strong indicator of the reproductive potential of an individual male $[15,16,20]$. In species with seasonal reproductive cycles (e.g. poultry), age and photoperiod influence the variation in testis weight and stereological characteristics of the germ cells in the SE of the fowl [21,22], turkey [23] and guinea-fowl [24,25].

The response of commercial poultry species to photoperiod is species specific. Male fowl raised under short-constant days (8L:18D) reached sexual maturity 3-4 weeks later than those subjected to a long-constant photoperiod (16L:8D) [21], whereas turkeys [23] or guinea-fowl males [24] subjected to comparable short-constant days (7L:17D) had sexual maturity delayed by 20-30 weeks. Subjecting male fowl [20], and guinea-fowl [25] to increasing photoperiods may, depending on the age at photostimulation, result in precocious and persistent testicular development over the reproductive season. The effect of increasing photoperiods on the onset of testicular development, germ cell populations and sperm output over the entire reproductive season in turkeys is not known. In the present study, three experiments were conducted to help elucidate the impact of age and 
photoperiod on testicular growth, semen output and on the histological and stereological characteristics of the SE during the reproductive season.

\section{Materials and methods}

\subsection{Experiment 1}

Male turkeys (BIG 6 medium; British United Turkeys (BUT), Chester, UK) were subjected to a 14L:10D photoperiod from 23 weeks of age. At 36 weeks of age, 34 males in semen production were weighed and euthanized with pentobarbital (Sanofi, la Ballastière 33501 Libourne, France; $1 \mathrm{~mL} / \mathrm{kg}$ body weight). Testes were removed, weighed, and cut in half. One piece was fixed at room temperature (RT) in Holland's Bouin (90\%, v/v) plus a saturated solution of mercuric chloride $(10 \%, \mathrm{v} / \mathrm{v})$. The other half was used immediately for cell quantification.

\subsubsection{Histology, stereological analyses and cell identification}

Fixed testes fragments were dehydrated in ethanol, embedded in paraplast and sectioned at $7 \mu \mathrm{m}$. Slides were stained with Mayer's hemalun $(1.5 \mathrm{~min})$ and 8GX Alcian blue (9 min). Stereological analysis included: relative volume $\left(V_{\mathrm{r}}\right)$ of seminiferous tubules $(\mathrm{ST})$; tubule diameter $(\varnothing)$; and populations of Sertoli cells (Sert), Type-I spermatocytes (SpcI), Type-II spermatocytes (SpcII), and round spermatids (SpdR). These cells were identified by their relative size, shape, and morphology of their nuclei [26] using a BH2-RFL Olympus microscope (Olympus Optical Co., Tokyo, Japan).

The $V_{\mathrm{r}}$ of individual ST was determined by point counting using a 25-point Hennig grid (Olympus Optical Co.). For each slide, 40 fields were randomly chosen and counted. This technique, first described by Chalkley [27], was previously validated in the fowl by de Reviers [2]. Mean diameters were obtained from 10 cross-sections of ST. Cross-sections were selected if the ratio of the minimum $\left(\varnothing_{\min }\right)$ diameter and maximum $\left(\varnothing_{\max }\right)$ diameter $\left(\emptyset_{\min } / \varnothing_{\max }\right)$ of the tubule was $\geq 0.85$.

\subsubsection{Measurement and quantitation of somatic and germinal cell populations}

Nuclei diameters in the seminiferous epithelium were obtained with an ocular micrometer using sections from five males and counting 20 nuclei/cell-type/male. Cell counts/transverse section (nSert, $\mathrm{nSpcI}, \mathrm{nSpdR}$ ) were estimated from 10 sections of individual ST/slide. Initial cell counts were corrected using Abercrombie's correction factor [28] as follows: $n=($ cell count/tubular section $) \times e /(\varnothing+e)$. Estimates of different cell populations per testis (NSert, NSpcI, and NSpdR) were determined as previously described by Brillard [5].

\subsubsection{Estimates of testicular sperm production (TSP)}

A fragment of approximately $1 \mathrm{~cm}^{3}$ from each testis (fwt) was weighed, homogenized in $200 \mathrm{~mL}$ of $0.25 \mathrm{M}$ sucrose, and elongated spermatids (el) and testicular spermatozoa (tspz) were counted using a hemacytometer (6 replicates/testis). Results for each male were 
expressed as follows: TSP/male $=$ right $\mathrm{TSP}+$ left TSP with TSP $=(\mathrm{el}+\mathrm{tspz}) / \mathrm{fwt} \times$ testesticular weight.

\subsection{Experiment 2}

Twelve turkeys (BIG 6 medium, BUT), 36-40 weeks of age and in semen production were anesthetized, the left testis exposed, and injected with $1 \mathrm{~mL}$ of 5-bromo- $2^{\prime}$ deoxyuridine (BrdU; Cell Proliferation Kit, Amersham, Buckinghamshire, UK). A lethal dose of pentobarbital was subsequently given to males $0.25,1-10$, and 17 days after BrdU injection. Both testes were isolated, weighed, fixed for 3 days in alcoholic-Bouin's fluid, dehydrated in ethanol, and embedded in paraplast. Sections $(7 \mu \mathrm{m})$ were incubated for $2 \mathrm{~h}$ at ambient temperature in anti-BrdU monoclonal antibody plus nuclease in a humidified chamber, washed in PBS, and then incubated again for $30 \mathrm{~min}$ at ambient temperature with peroxidase-conjugated anti-mouse IgG. Sections were flooded with $0.5 \mathrm{mg}$ of 3,3diaminobenzidine in $10 \mathrm{~mL}$ of phosphate buffer $(\mathrm{PB})$. The staining procedure was stopped by immersion of the slides in PB. All slides were counterstained with Mayer's hemalun for visualization of nuclear morphology. Sections from the right testis were used as controls.

Semen was collected daily from Days 11-17 from males scheduled to be sacrificed on Day 17. A $10 \mu \mathrm{L}$ aliquot of each semen sample was diluted (Sol I) in $1990 \mu \mathrm{L}$ of Lake's diluent [29]. A $50 \mu \mathrm{L}$ aliquot of the diluted semen was further diluted in Lake's diluent (plus $0.4 \%$ formaldehyde), to give a final semen dilution of 1:20,000 (v/v; Sol II). A $20 \mu \mathrm{L}$ aliquot of Sol II was placed on a slide, dried overnight, and then developed as described above for the detection of BrdU-labeled germ cells.

\subsection{Experiment 3}

\subsubsection{Animal husbandry}

A total of 105 immature breeder males (BIG 6 medium, BUT) were subjected to a progressively decreasing photoperiod ( $-1 \mathrm{~h} /$ week) from 11 to 17 weeks of age, and then maintained at a 7L:17D photoperiod up to 23 weeks of age. At 21 weeks of age, five males were randomly chosen and euthanized with pentobarbital. Body weights and individual testis weights were determined, and the testis was prepared as described previously for histology. The remaining males were randomly divided into four groups of 25 males each, and placed in environmentally controlled pens adjusted to $21 \pm 4{ }^{\circ} \mathrm{C}$. Group 1 was exposed to a photoperiod of 7L:17D, Group 2 to $10.5 \mathrm{~L}: 13.5 \mathrm{D}$, Group 3 to $14 \mathrm{~L}: 10 \mathrm{D}$, and Group 4 to 7L:17D that progressively increased in light to 14L:10D (+1 h/week from 23 to 29 weeks of age). All photoperiods began at 08:00 h, with incandescent bulbs adjusted to produce 25 lux at the height of males' heads. Feed and water were provided (per BUT guidelines) up to the end of the experiment (60 weeks of age).

\subsubsection{Estimates of weekly semen output (WSO)}

A total of 15 males per treatment were randomly chosen for further inter-group comparisons of WSO. A single daily semen collection performed for five consecutive days/ week was optimal for total WSO in the turkey [30]. Therefore, this schedule was performed in each group during the following weeks of age: 30-31; 33-34; 39-40; 45-46; 51-52; 57-58. 


\subsubsection{Estimates of body weights (BW), testicular weights (TW), WSO/TW, and TSP}

Five males from each group were weighed, sacrificed and their testes removed and weighed at 26, 29, 35, 48 and 60 weeks of age. In order to calculate the ratio WSO/TW in each group, males in semen production were randomly chosen and sacrificed at 35 and 60 weeks of age. Estimates of WSO/TW were deducted from WSO values obtained either at 33-34 weeks (for TW observed at 35 weeks) or at 57-58 weeks (for TW observed at 60 weeks). Pieces of testes were prepared for quantification of testicular sperm production, stereological analyses and quantitation of cell populations, as described previously.

\subsubsection{Quantitation of spermatogenesis}

In addition to $V_{\mathrm{r}}, \varnothing$, total length $\left(L_{\mathrm{t}}\right)$ of the ST, and NSert, NSpcI, NSpdR and TSP, we also estimated the meiotic ratio (MR). This was expressed as a theoretical ratio (TR\%) based on the mean MR of five males and calculated as follows: given that each SpcI should provide four SpdR during meiosis $(\mathrm{MR}=4)$, and that ultimately, the actual ratio of SpcI/ SpdR is dependent on the lifespan of each cell type, TR $\%=100(\mathrm{NSpdR} / \theta \mathrm{SpdR}) / 4$ (NspCI/ $\theta \mathrm{SpcI}$ ) [31]. $\theta$ denotes the life-span of a cell type determined from the BrdU observations.

\subsection{Statistical analyses}

For Experiments 1-3, testes weights, stereological parameters, and numbers of Sert, SpcI, SpdR, and TSP were analyzed by ANOVA and statistical significance among means estimated by Duncan's multiple range test. In Experiment 3, repeated measures were analyzed using an ANOVA (factorial-plan) and a Fisher protected least significant difference (PLSD) test when appropriate. Values with $P<0.05$ were regarded as significantly different. Correlation-matrix and $Z$ tests were used between testis weight, $V_{\mathrm{r}}$, $\varnothing$, nSert, nSpcI, nSpdR, and RM. Statview 4.5 software for PC computer was used for these analyses (Abacus Concept Inc., Berkeley, CA, USA).

\section{Results}

\subsection{Experiment 1}

\subsubsection{Histology of the seminiferous epithelium}

The general organization of the SE was similar to that in other poultry species. Sertoli cells were identified by their oblong shape and refringent nuclei most frequently observed between the spermatogonia (Spg) and SpcI populations (Fig. 1). In immature birds, only Sert and Spg populated the SE. Spermatogonia and their nuclei were characteristically large and round. Sertoli cell nuclei were oval shaped and smaller than Spg nuclei and appeared randomly distributed between the Spg in immature testis and between the Spg, SpcI, and SpcII's in mature testis. Three different types of Spg were identified in mature testis; they were differentiated based on nuclear diameter, heterochromatin appearance and distribution, and the relative position of the Spg to the ST basement membrane. The most frequently observed Spg (Spg1), the largest of the three, had a round-shaped nucleus about 


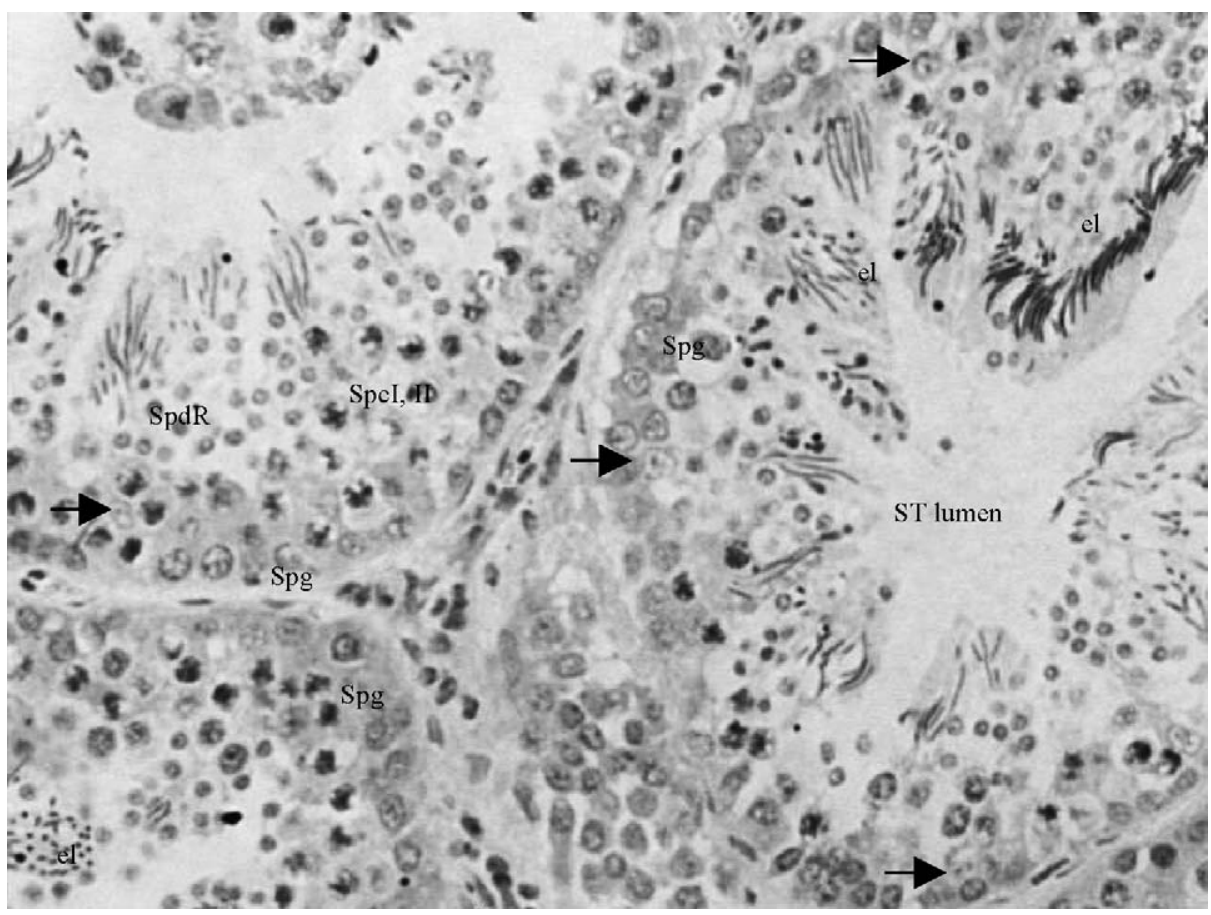

Fig. 1. Cross-sections of seminiferous tubules (ST) from a sexually mature turkey. Arrows highlight Sertoli cell nuclei between the spermatogonia (Spg) and larger, meiotic primary (SpcI) and secondary spermatocytes (SpcII). Round (SpdR) and elongating (el) spermatids are observed more toward the ST lumen. (arrows $=12 \mu \mathrm{m}$ ).

$6.6 \pm 0.1 \mu \mathrm{m}$ in diameter and contained dusty, pale heterochromatin (Fig. 1). The Spg1 cells were in direct contact with the ST basement membrane. The smallest Spg (Spg2) had a mean nuclear diameter of $4.2 \pm 0.1 \mu \mathrm{m}$ and possessed a bundled, well-stained heterochromatin. The Spg2 were not always associated with the ST basement membrane and were most frequently observed between the SpcI. The third type (Spg3) was darker, rarely observed, and had a mean nuclear diameter of 4.0-5.6 $\pm 0.2 \mu \mathrm{m}$. Its heterochromatin was dispersed in small bundles interconnected by narrow filaments. The Spg3 were always associated with the ST basement membrane (Fig. 1).

In mature turkeys, the SpcI nuclei had the largest diameters of any cell in the ST (Fig. 1). In the preleptotene stage, the nuclear diameter was about $6.9 \pm 0.1 \mu \mathrm{m}$ (Table 1b); its chromatin consisted of randomly dispersed, narrow filaments. In the leptotene and zygotene stages, nuclear diameters were about $6.5 \pm 0.1 \mu \mathrm{m}$, and its chromatin formed thickened eccentrically located filaments. As in the fowl [26,32], SpcI in the early pachytene stage contained thick and tortuous chromatin distributed throughout the nucleus.

Although rarely observed, the nuclei of SpcII were smaller than SpcI nuclei. The SpcII nuclei were characterized by thick clumps of chromatin, often associated with the nuclear membrane. Round spermatids were characterized by their small, spherical nucleus about $3.5 \pm 0.1 \mu \mathrm{m}$ in diameter (Table $1 \mathrm{~b}$ ) and located just above or between bundles of filiformshaped spermatids (Fig. 1). 
Table 1

Testes weights and stereological analysis of testicular components in sexually mature male turkeys subjected to a 14L:10D photoperiod from 23 weeks of age (Experiment 1)

(a) Testicular weights and seminiferous tubule stereology

\begin{tabular}{lllll}
\hline Testis & Weight $(\mathrm{g})$ & $V_{\mathrm{r}}(\%)$ & $\varnothing(\mathrm{m})$ & $L_{\mathrm{t}}(\mathrm{m})$ \\
\hline Left & $34.52 \pm 1.66^{\mathrm{b}}$ & $83.4 \pm 0.2^{\mathrm{a}}$ & $205.0 \pm 3.0^{\mathrm{a}}$ & $529.0 \pm 26.8^{\mathrm{b}}$ \\
Right & $19.36 \pm 1.31^{\mathrm{a}}$ & $83.1 \pm 0.3^{\mathrm{a}}$ & $200.7 \pm 2.1^{\mathrm{a}}$ & $322.2 \pm 21.1^{\mathrm{a}}$ \\
$P$ & $<0.0001$ & $>0.05$ & $>0.05$ & $<0.0001$
\end{tabular}

(b) Mean nuclear diameter $(\mu \mathrm{m})$ of selected germ cells

\begin{tabular}{lc}
\hline Spg1 & $6.6 \pm 0.1$ \\
Spg2 & $4.2 \pm 0.1$ \\
Spg3 & $4.0-5.6 \pm 0.2^{\mathrm{a}}$ \\
SpcI (prelept) & $6.9 \pm 0.1$ \\
SpcI (lept-dia) & $6.5 \pm 0.1$ \\
SpdR & $3.5 \pm 0.1$ \\
\hline
\end{tabular}

Values with different superscripts ( $a$ and $b$ ) differ significantly.

${ }^{a}$ Mean value of the smaller-larger diameter (oval shaped nuclei).

Testes weights (TW), $V_{\mathrm{r}}, \varnothing$, and $L_{\mathrm{t}}$ are presented in Table 1a. The left testes (L) was heavier than the right $(\mathrm{R})$ testes $(P<0.001)$ in 24 of 25 males examined, with a mean ratio of LTW/RTW $=0.56$. While there were significant differences in the $L_{\mathrm{t}}$ between LT and RT, there were no significant differences between testes in $V_{\mathrm{r}}$ and $\varnothing$ (Table 1a). No significant differences were observed per gram of testis (Table 2a) in individual males. However, the mean populations of NSert, NSpcI, or NSpdR, as well as TSP, were significantly greater in the left compared to the right testis (Table $2 b$ ). Total sperm production in the right testis was only $58 \%$ of the left testis.

\subsection{Experiment 2}

BrdU-labeled preleptotene SpcI were observed within $6 \mathrm{~h}$ after injection (Fig. 2A). On Days 1 and 2 following BrdU injection, zygotene and pachytene SpcI's were labeled and after Day 4, SpcII were labeled with BrdU. Early SpdR nuclei with uncondensed chromatin

Table 2

Numbers of Sert, SpcI, and SpdR in the left and right testes of sexually mature turkeys $(n=25)$

\begin{tabular}{llll}
\hline (a) Per gram of testis $\left(\times 10^{3}\right)$ & & \\
\hline Testis & Sert & SpcI & SpdR \\
\hline Left & $6.6 \pm 0.2^{\mathrm{a}}$ & $61.1 \pm 2.1^{\mathrm{a}}$ & $78.5 \pm 2.3^{\mathrm{a}}$ \\
Right & $6.3 \pm 0.2^{\mathrm{a}}$ & $54.4 \pm 1.2 \mathrm{~b}^{\mathrm{b}}$ & $75.0 \pm 2.8^{\mathrm{a}}$
\end{tabular}

(b) Per testis $\left(\times 10^{6}\right)$

\begin{tabular}{lllll}
\hline Testis & Sert & SpcI & SpdR & TSP (el + tspz) \\
\hline Left & $4.9 \pm 0.2^{\mathrm{x}}$ & $45.7 \pm 2.5^{\mathrm{x}}$ & $59.7 \pm 3.6^{\mathrm{x}}$ & $7.8 \pm 0.5^{\mathrm{x}}$ \\
Right & $2.9 \pm 0.2^{\mathrm{y}}$ & $25.3 \pm 1.9^{\mathrm{y}}$ & $34.7 \pm 2.8^{\mathrm{y}}$ & $4.6 \pm 0.3^{\mathrm{y}}$ \\
\hline
\end{tabular}

Values in columns with different superscripts differ $\left({ }^{\mathrm{a}, \mathrm{b}} P<0.05 ;{ }^{\mathrm{x}, \mathrm{y}} P<0.01\right)$. 

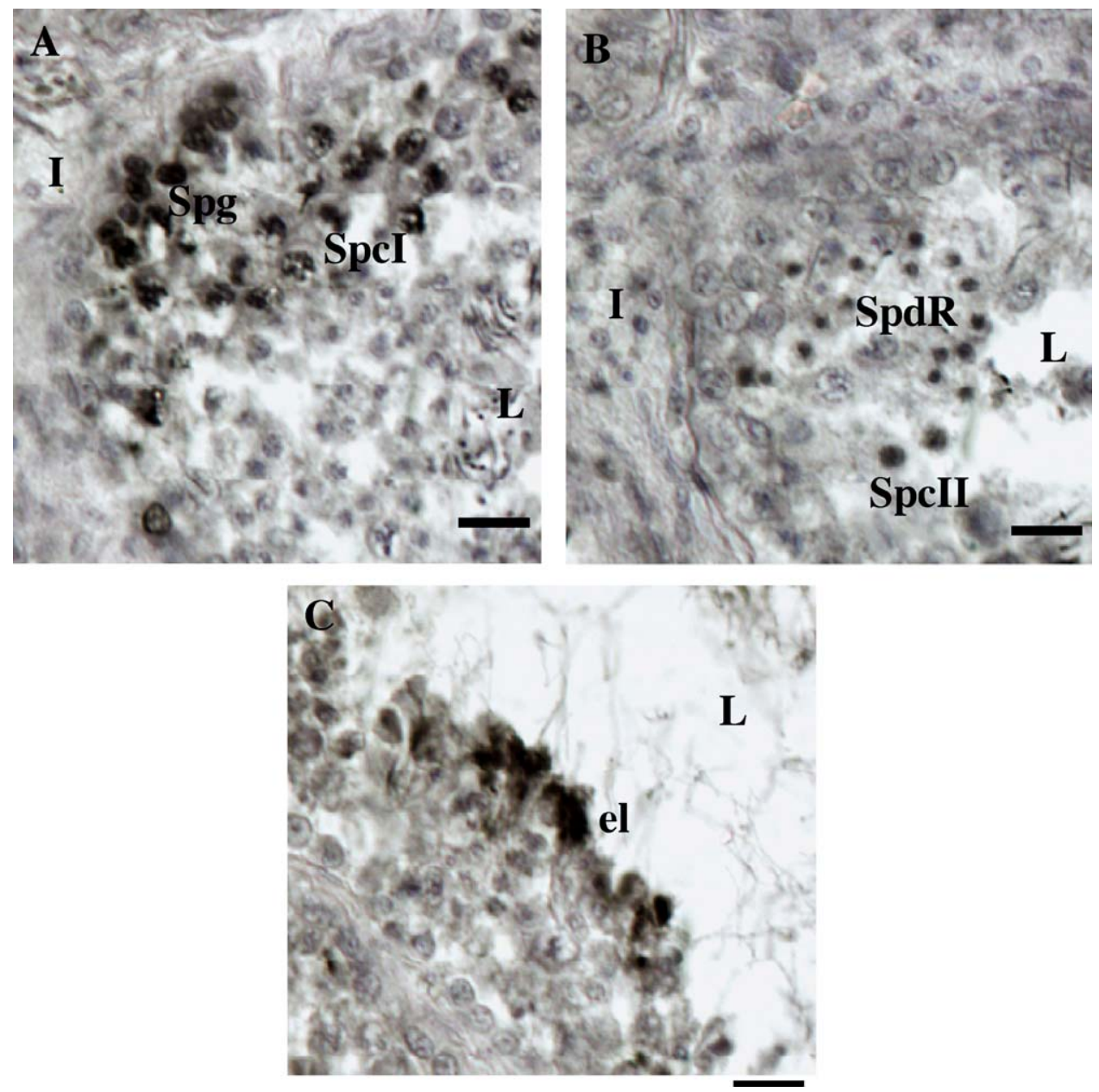

Fig. 2. BrdU-labeled preleptotene SpcI observed within $6 \mathrm{~h}$ after injection (A). SpdR were found labeled on Days 5 and 6 (B) and el were observed labeled on Day 7 (C).

and SpdR with more condensed chromatin were found labeled on Days 5 and 6, respectively (Fig. 2B). The most advanced germ cells labeled on Day 7 were elongating spermatids (Fig. 2C). From these observations, we extrapolated that the mean lifespan $(\theta)$ of $\mathrm{SpcI}(\theta \mathrm{SpcI})$ was 4.5 days and $\theta \mathrm{SpdR}$ was 2.0 days. Since BrdU reaction product was not detected on condensed elongated spermatids, the duration of complete spermatid elongation could not be estimated.

\subsection{Experiment 3}

\subsubsection{Body weights, testicular weights and weekly sperm output}

Body weights were similar $(P>0.05)$ among groups at all ages examined. Testes weights (Table 3 ) followed a different pattern between groups over the experimental 
Table 3

Testicular weights in breeder male turkeys subjected to various photoperiods over the reproductive season

\begin{tabular}{lllll}
\hline Age (weeks) & $7 \mathrm{~L}: 17 \mathrm{D}$ & $10.5 \mathrm{~L}: 13.5 \mathrm{D}$ & $14 \mathrm{~L}: 10 \mathrm{D}$ & 7L:17D to 14L:10D \\
\hline 21 & $3.2 \pm 0.5$ & & & \\
26 & $21.6 \pm 5.1^{\mathrm{a}, \mathrm{x}}$ & $26.2 \pm 3.9^{\mathrm{a}, \mathrm{x}}$ & $40.3 \pm 2.7^{\mathrm{a}, \mathrm{y}}$ & $19.6 \pm 9.2^{\mathrm{a}, \mathrm{x}}$ \\
29 & $21.0 \pm 9.8^{\mathrm{a}, \mathrm{x}}$ & $57.1 \pm 4.2^{\mathrm{b}, \mathrm{y}}$ & $59.4 \pm 4.4^{\mathrm{b}, \mathrm{y}}$ & $70.2 \pm 8.5^{\mathrm{b}, \mathrm{y}}$ \\
35 & $19.4 \pm 5.0^{\mathrm{a}, \mathrm{x}}$ & $71.1 \pm 12.2^{\mathrm{b}, \mathrm{y}}$ & $51.5 \pm 4.6^{\mathrm{b}, \mathrm{y}}$ & $64.0 \pm 8.6^{\mathrm{b}, \mathrm{y}}$ \\
48 & $22.2 \pm 5.5^{\mathrm{a}, \mathrm{x}}$ & $60.3 \pm 3.7^{\mathrm{b}, \mathrm{y}}$ & $47.1 \pm 3.9^{\mathrm{a}, \mathrm{b}, \mathrm{y}}$ & $36.2 \pm 4.5^{\mathrm{a}, \mathrm{x}, \mathrm{y}}$ \\
60 & $63.7 \pm 7.7^{\mathrm{b}, \mathrm{x}}$ & $49.4 \pm 8.7^{\mathrm{b}, \mathrm{x}}$ & $40.5 \pm 3.7^{\mathrm{a}, \mathrm{x}}$ & $49.3 \pm 4.2^{\mathrm{b}, \mathrm{x}}$ \\
\hline
\end{tabular}

Within the same column, values with different superscripts (a and $\mathrm{b}$ ) are different $(P<0.05)$. Within the same line, values with different superscripts $(\mathrm{x}$ and $\mathrm{y})$ are different $(P<0.05)$.

period, with an effect of age $(P<0.01)$ and treatment $(P<0.01)$. With the exception of Group 1 in which TW increased up to 60 weeks of age $(63.7 \pm 7.7 \mathrm{~g})$, all other groups had a rapid increase beginning at 21 weeks, reaching maximum weights at 29 weeks in Group 3 $(59.4 \pm 4.4 \mathrm{~g})$ and Group $4(70.2 \pm 8.5 \mathrm{~g})$, and at 35 weeks in Group $2(71.1 \pm 12.2 \mathrm{~g})$. This was followed by gradual decline in TW until 60 weeks. Due to the large interindividual differences observed within each group at each age (coefficients of variation ranging from 15 to $70 \%$ ), there were no significant differences between maximum TW. Accordingly, there were no significant differences among groups at 60 weeks of age, despite a tendency for greater TW in Group 1 compared to other groups $(P>0.06)$.

In the absence of significant differences between WSO values observed over two consecutive weeks within each group at each age tested, data obtained within two consecutive weeks were computed for further intra- and inter-group analyses. In general, WSO followed patterns similar to those observed for TW with maximum values observed at 32-33 weeks of age in Groups 3 and 4. Thereafter, WSO progressively declined to 57-59 weeks, where the WSO for Groups 2-4 ranged from $5.5 \pm 1.4 \times 10^{9}$ spermatozoa and $6.8 \pm 1.5 \times 10^{9}$ spermatozoa $(P>0.05)$. In Group 1 , WSO was below $1 \times 10^{9}$ spermatozoa up to 46 weeks, and then progressively increased up to 57-58 weeks of age (peaked at $3.6 \pm 0.8 \times 10^{9}$ spermatozoa). Like $\mathrm{TW}$, the large inter-individual differences among individuals within each group resulted in no statistical differences among groups at 57-58 weeks. In addition, the ratio WSO/TW were 10, 65, 89 and $143 \times 10^{6}$ spermatozoa/g at 34-35 weeks, and 30, 59, 59 and 94 spermatozoa/g at 59-60 weeks in Groups 1-4, respectively. Interestingly, the abdominal massage technique for collecting semen from Group 1 males (subjected to short photoperiods (7L:17D or $10.5 \mathrm{~L}: 10 \mathrm{D})$ ) required more vigorous stroking and squeezing of the cloaca to obtain phallic tumescence and ejaculation.

\subsubsection{Analysis of testicular components}

No significant effects of photoperiod were detected at 26 weeks of age for any parameter studied. In Group 1, values for $V_{\mathrm{r}}, \varnothing, L_{\mathrm{t}}$ (Fig. 3A-C) and NSert, NSpcI, NSpdR (Fig. 4A-C) increased up to 60 weeks of age. In Groups 2-4, the same values reached a plateau at 29-35 weeks, before undergoing a gradual decline from 36 to 60 weeks of age. At 60 weeks, there were no significant differences among the four groups for stereological parameters. Fig. 4D, depicting the MR for the four treatment groups, were similar to the overall patterns 


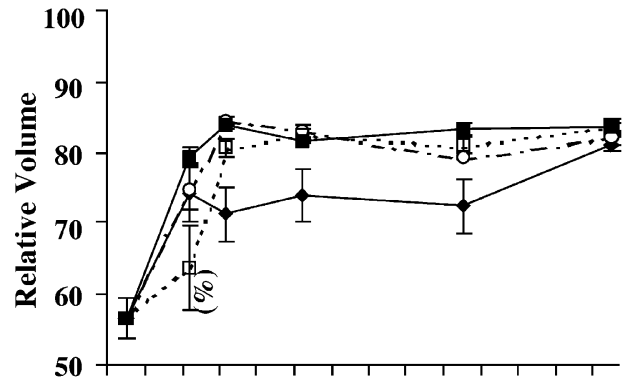

(A)
2023262932353841444750535659

Age (wk)

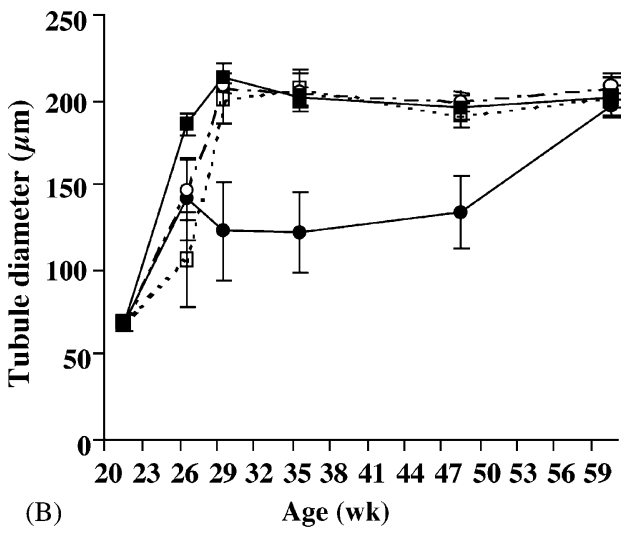

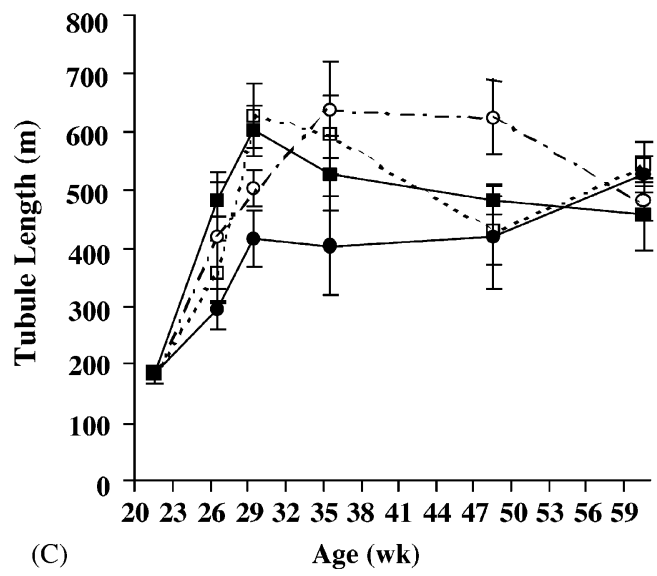

Fig. 3. Changes in relative ST volume (A), ST diameter (B), and ST length (C) over time under different photoperiods. Solid lines with solid circles (7L:17D; short photoperiod). Dashed lines with hollow circles (10.5L:13.5D; moderately short photoperiod). Solid lines with solid squares (14L:10D; long photoperiod). Dashed lines with hollow squares (start 7L:14D and added $1 \mathrm{~h} /$ week until 14L:10D; increasing photoperiod).

observed in TW and total cell numbers. Group 1 steadily increased through 60 weeks of age. In contrast, Groups 2-4 reached a maximum MR between 30 and 35 weeks (Fig. 4D).

\subsubsection{Estimates of testicular sperm production (TSP)}

There were effects of age and treatment $(P<0.01)$ on TSP between treatment groups (Fig. 5). In Group 1, TSP increased to 60 weeks of age (maximum TSP, $25.6 \pm 2.9 \times 10^{9}$ spermatozoa). Alternatively, TSP was maximum $\left(19.0 \pm 2.7 \times 10^{9}\right)$ at 29 weeks in Group 3 , and at 35 weeks for Groups $2\left(22.7 \pm 4.4 \times 10^{9}\right)$ and $\left(22.9 \pm 1.9 \times 10^{9}\right)$. Due to variation among individuals at a given age within each group, there were no significant differences in mean TSP among groups at their maximum. At 48 weeks of age, no difference between Group $1\left(4.6 \pm 1.9 \times 10^{9}\right.$ spermatozoa $)$ and Group $4\left(6.5 \pm 1.7 \times 10^{9}\right.$ spermatozoa) TSP rates was observed. However, for Groups $2(22.5 \pm 1.6 \times 109$ 

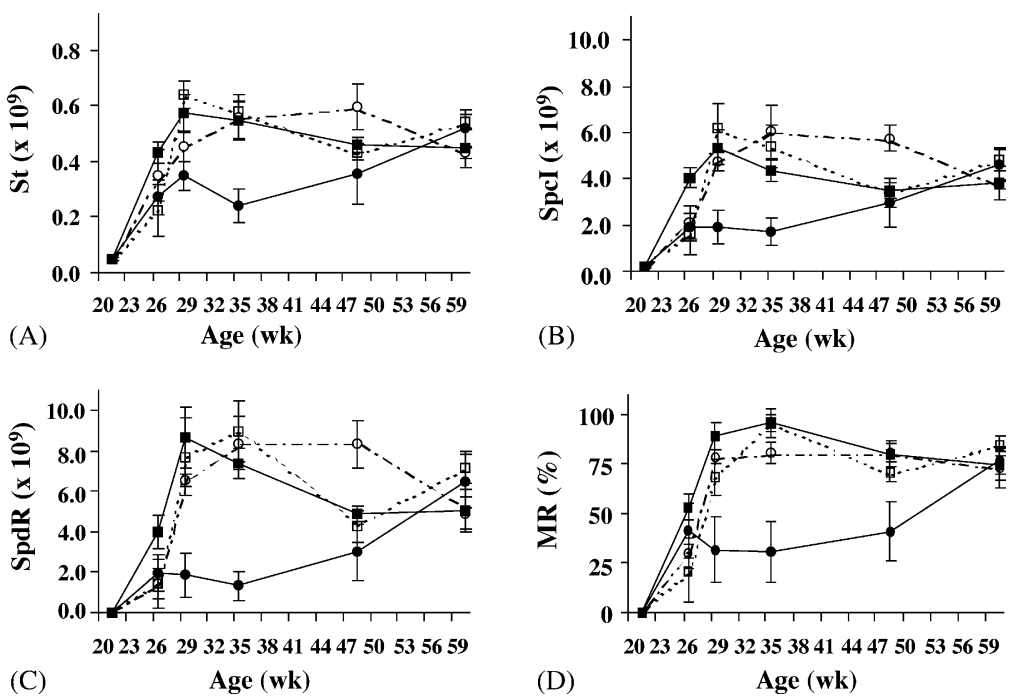

Fig. 4. Changes in Sertoli (A), Type-I spermatocyte (B), round spermatid (C) cell numbers, and the meiotic ratio (D) over time under different photoperiods. Solid lines with solid circles (7L:17D; short photoperiod). Dashed lines with hollow circles (10.5L:13.5D; moderately short photoperiod). Solid lines with solid squares (14L:10D; long photoperiod). Dashed lines with hollow squares (start 7L:14D and added $1 \mathrm{~h} /$ week until 14L:10D; increasing photoperiod).

spermatozoa $)$ and $3(15.3 \pm 2.6 \times 109$ spermatozoa $)$ TSP rates were significantly different from each other and from Groups 1 and 4. At 60 weeks, no significant differences were observed, either between Groups 3 and 4, or between Groups 1 and 2 (Fig. 5).

\subsubsection{Interrelationships between $T W, V_{n}, \emptyset, n S e r t, n S p c I, n S p d R, M R$, and TSP}

There were no significant differences between groups and ages for all stereological parameters analyzed. Therefore, data from all testes were pooled for analysis of possible

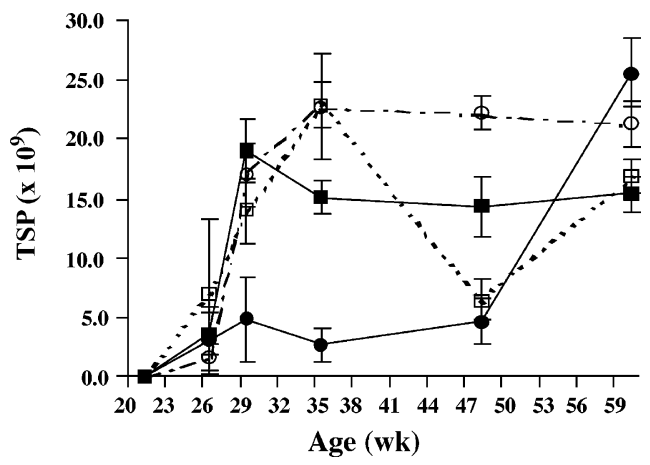

Fig. 5. Changes in testicular sperm production over time under different photoperiods. Solid lines with solid circles (7L:17D; short photoperiod). Dashed lines with hollow circles (10.5L:13.5D; moderately short photoperiod). Solid lines with solid squares (14L:10D; long photoperiod). Dashed lines with hollow squares (start 7L:14D and added $1 \mathrm{~h}$ /week until 14L:10D; increasing photoperiod). 
Table 4

Correlation coefficients and probability ( $Z$ test) between testis weights (TW), $V_{\mathrm{r}}, \varnothing, \mathrm{nSert}, \mathrm{nSpcI}, \mathrm{nSpdR}, \mathrm{MR}$, and TSP

\begin{tabular}{|c|c|c|c|c|c|c|c|c|c|c|c|c|c|c|c|c|}
\hline & \multicolumn{2}{|l|}{ TW } & \multicolumn{2}{|l|}{$V_{\mathrm{r}}$} & \multicolumn{2}{|l|}{$\varnothing$} & \multicolumn{2}{|l|}{ nSert } & \multicolumn{2}{|c|}{$\mathrm{nSpcI}$} & \multicolumn{2}{|c|}{ nSpdR } & \multicolumn{2}{|l|}{ MR } & \multicolumn{2}{|c|}{ TSP } \\
\hline & $r$ & $P$ & $r$ & $P$ & $r$ & $P$ & $r$ & $P$ & $r$ & $P$ & $r$ & $P$ & $r$ & $P$ & $r$ & $P$ \\
\hline TW & 1 & - & & & & & & & & & & & & & & \\
\hline$V_{\mathrm{r}}$ & 0.77 & $*$ & 1 & - & & & & & & & & & & & & \\
\hline$\varnothing$ & 0.86 & $*$ & 0.94 & $*$ & 1 & - & & & & & & & & & & \\
\hline $\mathrm{nSt}$ & 0.64 & $*$ & 0.83 & $*$ & 0.81 & $*$ & 1 & - & & & & & & & & \\
\hline nSert & 0.86 & $*$ & 0.87 & $*$ & 0.95 & $*$ & 0.79 & $*$ & 1 & - & & & & & & \\
\hline $\mathrm{nSpdR}$ & 0.87 & * & 0.82 & $*$ & 0.91 & * & 0.72 & * & 0.90 & $*$ & 1 & - & & & & \\
\hline MR & 0.79 & $*$ & 0.86 & $*$ & 0.89 & * & 0.74 & * & NA & - & NA & - & 1 & - & & \\
\hline TSP & NA & - & 0.63 & $*$ & 0.73 & $*$ & 0.51 & $*$ & 0.69 & * & 0.79 & $*$ & 0.73 & $*$ & 1 & - \\
\hline
\end{tabular}

NA: not applicable (dependent measures).

* $P<0.0001$.

correlations between testis weight, $V_{\mathrm{r}}, \varnothing, \mathrm{nSert}, \mathrm{nSpcI}, \mathrm{nSpdR}, \mathrm{MR}$, and TSP (Table 3). Correlation coefficients between $L_{\mathrm{t}}$, NSert, NSpcI, and NSpdR were not estimated due to the causal dependence between these parameters. There were correlations $(P<0.0001)$ between all parameters tested, with values ranging from 0.51 to 0.95 between nSert and TSP or $\varnothing$ and nSpcI (Table 4). Testicular weights were highly correlated with $\varnothing, \mathrm{nSpcI}$ and $\mathrm{nSpdR}(r=0.86-0.87)$. Among other parameters tested, MR was highly correlated with all other testicular components (values ranging from 0.73 to 0.89 ), whereas TSP generally had the lowest correlation coefficients.

\section{Discussion}

In this study, the impact of photoperiod on the quantitative aspects of testes development and germ cell stereology was examined in the male breeder turkey. Regardless of photoperiod, morphological and stereological characteristics of turkey testes were similar to those of the fowl and guinea-fowl. In mature turkeys, 85-90\% of the relative volume of the testes was occupied by the ST, very similar to the fowl [2] and guinea-fowl [9]. The histology of the turkey SE seemed identical to that previously described in the fowl and guinea-fowl. We did not observe a pattern of germ cell associations within the turkey's SE. Although these associations have not been observed in the fowl or guinea-fowl SE, there is a single report that described several stages of germ cell associations in the quail SE [33]. However, these authors based their observations on a single quail and other investigations with quail [10] failed to detect these associations.

Based on the appearance of BrdU-positive cells, the duration of meiotic prophase (SpcI) in the turkey was estimated to be 4.5 days, whereas $\mathrm{SpdR}$ had an estimated duration of 2 days. These intervals were similar to observations reported in the fowl (5.5 and 2.5 days, respectively) [12], the drake (5.0 and 2.0 days, respectively) [13] and the quail (3.9 days for meiotic prophase) [32]. No BrdU-reaction product was observed on el and tspz. Apparently, condensation of the nuclear chromatin masked the BrdU, the anti-body to BrdU could not penetrate the condensed chromatin, or both. 
The effect of the treatment photoperiods on TW, SE histology, and testicular maturation were more similar to the guinea-fowl [24,25] than the fowl [20-22]. With a strictly short photoperiod (Group 1), TW and weight-correlated testicular parameters, including $L_{\mathrm{t}}$, NSert, NSpcI, NSpdR and TSP, reached a plateau between 26 and 48 weeks of age, and then increased to the end of the experiment (60 weeks). In contrast, with long constant (Groups 2 and 3) or increasing photoperiods (Group 4), TW and the weight-correlated testicular parameters reached maximum values at 29-35 weeks of age. While there were no significant differences in BW among the four groups, it was clear that the longer photoperiods used in Groups 2-4 had a stimulatory effect on TW and on weight-correlated testicular parameters. Interestingly, after Groups 3 and 4 peaked at 29 weeks, slight declines in TW and the weight-correlated testicular parameters were observed through 60 weeks of age, in agreement with observations from the fowl and guinea-fowl [19-22].

The onset of sexual maturity relative to the length of the photoperiod vary among domestic birds. As previously observed in guinea-fowl [24], sexual maturity was delayed by almost 30 weeks in strictly short photoperiod males compared to long photoperiod (Group 3). In contrast, fowl males subjected to a strictly short photoperiod reached sexual maturity only 3-6 weeks after that observed in males subjected to a strictly long (16L:8D) photoperiod [21]. Based on our observations, it is suggested that the threshold of photosensitivity to gonad stimulation in male turkeys is between 7.0 and $10.5 \mathrm{~h}$ of light. The highly positive correlations observed in this study between TW and germ cell populations supported this assertion. Therefore, it can be concluded that most of the variability of the TW in the turkey, fowl, and guinea-fowl can be explained by the variations in the testicular germ cell populations [22,25]. How photoperiod influences testicular development in turkeys and, in domestic birds in general, needs to be more clearly elucidated. In turkeys, plasma concentrations of LH and testosterone are dependent on age and photoperiod [38]. In chickens, the pathways through which a photoperiodic signal stimulates LH secretion in the pituitary may involve local pineal-driven mechanisms associated with mechanisms originating in the retina [39]. More information is needed to better understand the mechanisms involved in the perception, transmission and transduction of the photoperiodic signal in the initiation and maintenance of testes in photosensitive birds.

Our observations of significant differences between testes weight within individual male turkeys supported observations by Burke [34] and Cecil and Bakst [35,36]. Hocking [37] observed that the left testis was heavier than the right in $67 \%$ of the male chickens, but concluded that the differences in weights were minor. The basis for testicular asymmetry remains unknown but may be due to an unequal number of primordial germ cells incorporated into the embryonic gonads.

In conclusion, early onset of testicular development in turkey males subjected to a strictly short photoperiod (7L:17D) was dramatically delayed (approximately 30 weeks) compared to males subjected to a constant long photoperiod (14L:10D). By contrast, testicular development was only slightly delayed ( $\leq 3$ weeks) in males subjected to a moderately short photoperiod (10.5L:13.5D) compared to males subjected to a long constant photoperiod (14L:10D). However, a moderately short photoperiod more effectively maintained spermatogenesis in middle-aged males. Furthermore, the response to manual semen collection by males subjected to strictly (7L:17D) or moderately short 
photoperiods (10.5L:13.5D) differed from other males; those on the longer photoperiods (14L:10D and 7L:17D to 14L10D) readily ejaculated in response to abdominal massage, whereas those subjected to a strictly (7L:17D) or moderately (10.5L:13.5D) short photoperiod responded less rapidly and less efficiently to massage. Finally, from a quantitative perspective, germ cell populations and meiotic ratios should be considered pertinent histological parameters to depict reproductive stages in breeder male turkeys.

\section{Acknowledgements}

The authors wish to thank Dr M. de Reviers for his useful comments and proposals regarding the set up of this experiment. Also, the authors are indebted to Mr. C. Staub and to Dr. P. Durand for pointers on the use of BrdU kit and Dr. C. Gossage for helpful discussions regarding the manuscript.

\section{References}

[1] Kumaran JDS, Turner CW. The normal development of testes in the White Plymouth Rock. Poult Sci 1949;28:511-20.

[2] de Reviers M. Le développement testiculaire chez le coq. I. Croissance pondérale des testicules et développement des tubes séminifères. Ann Biol Anim Biochem Biophys 1971;11(4):519-30.

[3] Clulow J, Jones RC. Production, transport, maturation, storage and survival of spermatozoa in the male Japanese quail, Coturnix coturnix. J Reprod Fertil 1982;64:259-66.

[4] Marchand CR, Gomot L. Le cycle testiculaire du canard de barbarie (Cairina moschata L.). Bull Assoc Anat 1973;57:157.

[5] Brillard JP. 1986 Age-related variations in seminiferous dimensions and germinal and Sertoli cell numbers in guinea-fowl raised under a 14L:10D photoperiod. Poult Sci 1986;65:369-74.

[6] Courot M, Hochereau de Reviers MT, Ortavant R. Spermatogenesis. In: Johnson AD, Gomes WR, Vandemark NL, editors. The testis, vol. 1. New York: Academic Press; 1970. p. 339-432.

[7] Clermont Y. Différenciation et évolution des cellules sexuelles $1^{\circ}$ la lignée mâle. Cinétique de la spermatogénèse chez les mammifères. Arch Anat Microsc 1967;56:7-60.

[8] Clermont Y. Structure de l'épithélium séminal et mode de renouvellement des spermatogonies chez le canard. Arch Anat Microsc 1958;47:47-66.

[9] Aire TA, Olowo-okorun MO, Ayeni JS. The seminiferous epithelium in the guinea-fowl (Numida meleagris). Cell Tissue Res 1980;205:319-25.

[10] Yamamoto S, Tamate H, Itikawa O. Morphological studies on the sexual maturation in the Japanese quail (Coturnix coturnix japonica). II The germ cell types and cellular associations during spermatogenesis. Tohoku J Agric Res 1967;18:27-37.

[11] Lake PE. Male genital organs. In: King AS, McLelland J, editors. Forms and functions in birds. London: Academic Press; 1981. p. 2-61.

[12] de Reviers M. Détermination de la durée des processus spermatogénetiques chez le coq a l'aide de thymidine tritiée. VIe Cong Intern Reprod Anim Insem Artif Paris 1968;1:183-5.

[13] Marchand CR, Gomot L, de Reviers M. Etude par autoradiographie et marquage à la thymidine tritiée de la duréede la spermatogénèse du canard de barbarie (Cairina moschata L.). CR Soc Biol 1977;171:92731.

[14] Oakberg EF. Duration of spermatogenesis in the mouse and timing of stages of the cycle of the seminiferous epithelium. Am J Anat 1956;99:507-16.

[15] Ortavant R. Action de la durée d'éclairement sur les processus spermatogénétiques chez le bélier. CR Soc Biol 1956;150:471. 
[16] Hochereau MT, Courot M, Ortavant R. Durée de la spermatogénèse chez le taureau; étude par autoradiographie testiculaire. In: Proceedings of fifth international congress on animal reproduction, Trento; 1964. p. 541.

[17] Heller CG, Clermont Y. Kinetics of the germinal epithelium in man. In: Pincus G, editor. Recent progress in hormone research, vol. 20. New York: Academic Press; 1964. p. 545-75.

[18] Amir D, Braun-Eilon B, Schindler H. Passage and disappearance of labelled spermatozoa in the genital tract of the Japanese quail in segregation or cohabitation. Ann Biol Anim Biochem Biophys 1963;13:321-8.

[19] Brillard JP. Influence de la photopériode quotidiènne sur le développement des testicules et sur l'établissement de la spermatogénèse chez la pintade. Thesis, University of Tours, Tours, France; 1981.

[20] de Reviers M. Le développement testiculaire chez le coq. IV. Étude quantitative des cellules germinales du coq placé sous des photopériodes croissantes appliquées à des âges différents. Ann Biol Anim Biochem Biophys 1975;15:633-41.

[21] de Reviers M. Le développement testiculaire chez le coq. III. Influence de la durée quotidienne d'éclairement sous photopériodes constantes. Ann Biol Anim Biochem Biophys 1974;14:591-600.

[22] de Reviers M. Le développement testiculaire chez le coq. V. Action de variations progressives de la durée quotidienne d'éclairement. Ann Biol Anim Biochem Biophys 1977;17:179-86.

[23] Krueger KK, Owen JA, Krueger CE, Ferguson TM. Effect of feed or light restriction during the growing and breeding cycles on the reproductive performance of broad breasted white turkey males. Poult Sci 1977;56:1566-74.

[24] Brillard JP, de Reviers M. Testis development and daily sperm output in guinea-fowl raised under constant daily photperiods. Reprod Nutr Dévelop 1981;21:1105-12.

[25] Brillard JP, de Reviers M. Testis development and daily sperm output in guineas submitted to progressively increasing daily photperiods at different ages. Poult Sci 1985;64:713-7.

[26] de Reviers M. Le développement testiculaire chez le coq. II. Morphologie de l'épithélium séminifère et établissement de la spermatogénèse. Ann Biol Anim Biochem Biophys 1971;11:531-46.

[27] Chalkley HW. Method for the quantitative morphologic analysis of tissues. J Natl Cancer Inst 1943;4:47-73.

[28] Abercrombie M. Estimation of nuclear population from microtome sections. Anat Rec 1946;94:239-47.

[29] Lake PE, Ravie O. Effect on fertility of storing turkey semen for $24 \mathrm{~h}$ at $10{ }^{\circ} \mathrm{C}$ in fluids of different $\mathrm{pH}$. $\mathrm{Br}$ Poultry Sci 1982;32:41-7.

[30] Noirault J, Brillard JP. Effects of frequency of semen collection on quantitative and qualitative characteristics of semen in turkey breeder males. Poult Sci 1999;78:1034-9.

[31] Amann RP. Sperm production rates. In: Johnson AD, Gomes WR, Vandemark NL, editors. The testis, vol. 1. New York: Academic Press; 1970. p. 433-82.

[32] Zlotnik I. The cytoplasmic components of germ-cells during spermatogenesis in the domestic fowl. Q J Microsc 1947;88:353-65.

[33] Lin M, Jones RC, Blackshaw AW. The cycle of the seminiferous epithelium in the Japanese quail (Coturnix coturnix japonica). J Reprod Fertil 1990;88:481-90.

[34] Burke WH. Testicular asymmetry in the turkey. Poult Sci 1973;52:1652-4.

[35] Cecil HC, Bakst MR. Testicular weights, ductus deferens semen volumes, and sperm concentration of turkeys with high and low ejaculate volumes. Poult Sci 1984;63:1432-7.

[36] Cecil HC, Bakst MR. Daily output of spermatozoa and extragonadal spermatozoal reserves in turkeys. Poult Sci 1988;67:327-32.

[37] Hocking PM. Bilateral testicular asymmetry and supernumerary testes in the domestic fowl (Gallus domesticus). Br Poult Sci 1992;33:455-60.

[38] Yang J, Long DW, Inpanbutr N, Bacon W. Effect of photoperiod and age on secretory patterns of luteinizing hormone and testosterone and semen production in male domestic turkeys. Biol Reprod 1998;59:1171-9.

[39] Zawilska JB, Berezinska M, Rosiak J, Skene DJ, Vivien-Roels B, Nowak JZ. Suppression of melatonin biosynthesis in the chicken pineal gland by retinally percived light-involvment of D1-dopamine receptors. $\mathrm{J}$ Pineal Res 2004;36:80-6. 